\title{
12 Epilogue
}

\section{Security without society?}

\author{
J. Peter Burgess
}

\section{July 2011}

At 3:25 P.M. on 22 July 2011 a terrorist's bomb went off in a van parked immediately in front of the Norwegian government headquarters in downtown Oslo. The building housed the Prime Minister's offices and the Ministry of Justice. The shockwave caused by the explosion broke windows and shook buildings in a radius of up to several hundred meters. The explosion killed 8 people outright and injured 209, 12 of them serious, and caused heavy damage to several buildings in the quarter.

At Utøya, a 10 hectare island located in the Tyri Fjord 38 kilometres northwest of Oslo, the same terrorist, who had departed from Oslo centre in a second vehicle just prior to the explosion, arrived at the ferry dock just over an hour later. Dressed in a police uniform he hailed the island ferry and arrived on Utøya. He immediately approached a small group of people near the quay, including the camp manager and the off-duty police officer hired for security. After a brief exchange he shot them both dead, then began a 90-minute shooting spree before surrendering to the police. Of the over 600 people on the island 68 were killed outright, and 110 were injured, 55 of them grave. One additional victim died in hospital two days later (NRK, 2011).

Dagsrevyen, the centrepiece evening news programme of the Norwegian Broadcasting Company, went on the air as scheduled at 7:00 P.M., only 3.5 hours after the explosion in the centre of Oslo. The opening vignette showed scenes of damage and destruction in the streets of the capital. Windows were blown out in entire buildings, fire and smoke still appeared from broken and fragmented walls and gaping window frames. Images of ambulances, emergency vehicles, and rescue personnel traversed the silent frame. A gurney silently appeared carrying a disfigured victim. As the voice-over began, footage of a middle-aged light-haired woman appeared, her face completely bathed in her own blood, moving to safety with the help of a second woman holding her hand. The image would have been petrifying coming from any distant war-zone. To viewers of the evening news of this provincial nation, schooled in solidarity, accustomed to consensus politics and low-crime society, and a self-affirmed 'culture of peace', it was utterly shocking. 
The news anchor began: 'The situation in Oslo is very uncertain for police, and police ask people to stay away from the centre and avoid large gatherings of people'. Indeed, the situation was so unclear in many respects, with only fragments of confirmed information available. Was the attack over? Were more perpetrators involved? Were there still elements to the attack that were yet unknown? What was the link between the two events? Uncertainty seemed total, about what in fact had happened, about what was continuing to happen, about how many and who were hurt or killed, about who was responsible, and about the complex chain of events still unfolding on the island of Utøya. All of this unfolded live on the most watched programme on national television.

All these questions were to remain unanswered for some time. Finally at 8:00 P.M., 1 hour after the beginning of the news programme the Prime Minister appeared on television from an undisclosed location, speaking to a reporter, clearly shaken, nervous, tense, perspiring, and grave. Despite the extraordinary situation and uncanny ambiance, the Prime Minister firmly formulated a principle that would be repeated over the course of the next days and weeks, and which would become the hinge to the question of liberal approaches to illiberalism in many settings across the world:

it is important to not let fear take the overhand. We want in times exactly like these to stand up for what we believe, an open society, a society where political activity can take place in safety without threats, and where violence will not frighten us away from normal activity

(NRK, 2011).

For the next four hours of the broadcast, the strange dialectic of certainty and uncertainty cruelly played out: the more one knew, the more the scope of the unknown grew. The details of the horrific attacks fed an economy of longing for knowledge and, more gravely, for understanding what was happening. Neither the experts nor government figures were able to say who the enemies were, what they wanted, and how or to what degree they had done damage. Slowly, over the course of the night and the next days, a more pathos-filled question began to appear on the lips of both citizens and expert commentators: the question of 'why?' Why would anyone want to hurt us? What have we done? Of what are we guilty in the eyes of the perpetrators?

Can 'societal security' as a concept or as a toolbox help us to navigate this complex social, political, cultural, moral, spiritual territory? This book presents evidence that it can.

\section{Modelling Nordic societal security}

A plausible social scientific path to exploring the societal correlate of any concept or phenomenon - 'security', among others - is to chart its variation across a range of empirical values, contexts, settings, ('dependent variables'). 
On this methodological argument, and before asking more culturally sensitive questions about the 'nature' or the 'character' of Nordic societies, the present volume presents a valuable exercise in collecting contributions about and around the concept of Nordic societal security. The research groups at the origin of these chapters have sustained a multi-year dialogue about research on societal security, understood on more or less uniform set of criteria, about a set of more or less consensually accepted objects (Larsson and Rhinard, this volume). Thus, Larsson traces Swedish societal security thinking in a period of civil defence reforms and threat reconstructions. Morsut charts the parallel evolution of the concept of 'samfunnssikkerhet' in Norwegian public policy, which for reasons that are clarified in her contribution, she leaves untranslated. Valtonen and Branders present and analyse the evolution of the Finnish 'comprehensive security model'. Liebetrau analyses the theoretical mutation of societal security thinking toward a deeper concern with uncertainty within the Danish defence. Others place societal security in a constellation of other concepts. Juntunen and Hyvönen offer a transversal mapping of a security concept ('resilience') that enacts a kind of resistance to the Norwegian and Swedish historical trend toward harmonisation of societal security thinking in institutional practices. For Jore it is correlated with the parallel discourse of the terrorist radicalisation and de-radicalisation. In the Swedish sub-case, Stiglund usefully correlates it with the rising and ever-evolving discourse of risk. As Villumsen Berling and Lund Petersen show, the Nordic region is one in which the concept of societal security is far from dominant, and where a significantly politicised concept such as resilience in fact has more analytic traction.

In short, the project of capturing the Nordic model can, on the one hand, be understood in a nearly observational mode as an answer to the question 'how is the idea of societal security used in the Nordic countries?' However as Larsson and Rhinard show, each in his own way, the concept of Nordic societal security does not bear out this scientific innocence, but is rather the issue of political processes that ironically might have been interpreted as an expression of Nordic societal insecurity and the search to fortify the meaning, legitimacy, and singularity of the Nordic.

Since the mid-20th century the concept of a 'Nordic model' has had a progressive social democratic aura about it. The perceived success of social welfare models, minimal earning inequality, low crime rates, strong norms of gender parity, and consistently high scores on popularised 'happiness' indexes - Finland, Denmark, Norway, Iceland, and Sweden rank 1, 2, 3, 4, and 7, respectively, in the 2019 World Happiness Report (Helliwell et al., 2019) - have contributed to a kind of Nordic mythology (Aylott, 2014; Brandal et al., 2013; Hilson, 2008). Supported by the good moral standing with which the Nordic communist and social democratic political parties emerged from the rubble of the Second World War, 20th-century industrialisation and globalisation processes were shepherded with strong centralised economies and robust labour unions. Despite the derisive cultural critique 
of some, like Witoszek's The Origin of the "Goodness Regime" (2011) and the right-wing complaints of the "overbearing kindness" (snillisme) toward immigrant communities (NTB, 2016), the myth of the Nordic model has flourished, becoming a cottage industry for Nordic 'reputation management'. The legend of the Nordic model makes for good geopolitics and international finance. The Nordic model is good business and good politics.

Something like a Nordic model did indeed emerge after the Second World War, characterised by close cooperation between social democratic political parties and the blue-collar trade unions, well-functioning multi-party systems, a consensual approach to policy making, systematic consultations across societal sectors, centralised systems of collective bargaining, active role of the state in market regulation, and the personalisation of relations among the political elites (Arter, 1999; Kvist and Fritzell, 2011; Kvist and Greve, 2011). In short, the Nordic countries are thought to share a pragmatic approach to governing one based on personal relations, a closely knit governing and bureaucratic class, shared values, and an informal, customarybased approach to policy-making and political problem-solving.

Similar qualities characterise the more or less shared structures and customs of welfare-state economies. Its origins are frequently traced to the Depression era book by Marquis W. Childs, Sweden: The Middle Way, which from Sweden's position of neutrality during Second World War situated Sweden socio-economically between the destitution of US capitalism and the overreach of Soviet communism (Childs, 1936). The robust pragmatic model of governance then underwrites the components of the Nordic welfare state, characterised by citizenship-based social rights, strong or monopoly public sector role in the planning of public services, comprehensive social-policy provision, strong income distribution based on explicitly ideologies of social equality (Arter, 1999; Dølvik, 2007; Greve et al., 2016).

This chapter was opened by evoking the $22 / 7$ Norway attacks to suggest that, while there is considerable interest in this volume and elsewhere in exploring the origins and institutional trajectory of the concept of societal security, these studies tell only part of the story. In the Oslo/Utøya case, they tell us little about the spiritual wave that washed over Norway in the hours, days, weeks, even years after the attacks of 22 July 2011, a wave that touched the other Nordic countries and the rest of the world as well. It cannot account for moral life of Nordic culture and of those who witness, remember, or fear violence, either close at hand or at distance. It does not bring us closer to understanding the creation and evolution of community through, around, and within the experience of danger. It does not fully consider the close but ever-changing relation between the experience of security and that of community, that a community is both always under threat and as a fundamental security-giving force. It does not search out correlation between values and life. It does not account for the forces at work to transform human energies fear, anger, sadness - into political expression. It cannot help us to better grapple with the scientific pretences that seem to be our only tools for 
analysing the experience of the proximity of death, of association with those that are gone, or of the Nordic values shared with a killer.

\section{Non-societal ways of securing society}

In all fairness, the contributions to this book have not done these things because they have not sought to. They have had other valid and valuable objects to attend to. And yet, as this epilogue will try to show, with the social scientific foundations of societal security laid, there is a considerable horizon that is now opening to understand societal security as a problem for the human sciences, as a cultural, ethical, psychoanalytical, and even spiritual question.

Perspectives like this would help us to understand the Oslo and Utøya attacks, and to better explain the radical evolution that has taken place in societal security thinking in the Nordic countries and elsewhere nearly a decade after, and how the discourses surrounding them have transformed themselves into a kind of instrumental security governance: logistical questions, boats and helicopters, radios and databases, traffic patterns, engineering methods, chains of command, organisational procedures, institutional communication, accountability, and emergency powers.

Forgotten is the nature of insecurity of not only that day, but of the days, weeks, and months following it, the residual insecurity that lives on in the hearts and minds of Norwegians and others. Gone is the memory of the immediate lived insecurity of that day and today, the way it reached into the personal experiences of individual lives, how both fear, comfort, courage, and resolve grew out of people and their relations with other people. The fear felt by Norwegians and others that day was not only for life, but for a way of life, a culture, a self-image, for individual and collective values. This was proclaimed over and over again, but with gradually decreasing regularity, in the wake of the attacks. This was an attack against 'us', it was said, against who 'we' are, what we believe, our way of life, etc. It transcended the loss and suffering of the immediate victims. The threat was to something that lived before and lives on after. Also long forgotten is the uncanny realisation, particularly in the immediate aftermath, that society itself was by far the most meaningful resource. Also misunderstood, misplaced, and mistaken is the immediate awareness for anyone who was present in Norway during the aftermath that the unparalleled source of security of Norwegians was - and of course is still - society itself.

Lived insecurity is of course the only insecurity there is. It is only by a ruse of language that we speak of the insecurity of inanimate things. A bridge, a railroad line, or an oil platform is insecure only in the sense that it is imbued with lived insecurity. Only in the sense that the steel and concrete is part of human relations, not as a 'function', but as material imbedding of life and social relations. As much as pundits and scientists alike will argue that a bridge, a railroad line, or an oil platform is an object of societal security, 
this can only become meaningful once we discover their social function. If the concept of societal security has so far done good work, it still holds the potential to do more.

For, at the risk of appearing trivial: there is societal insecurity only, well, if society is insecure.

Where does one start to ask and answer the question of 'society' in societal security? Sorting out, documenting, and analysing what actually takes place in a given event; what the 'facts' are; what the precise circumstances were; and are the chain of events, the direction of the causality, and the identity of the legal subjects to be ascribed legal responsibility, these are the questions for first-line forensic analysis of an event. Such first-order legal protocols require only an entirely de-personalised narrative of the episode, a series of actions and events that together form a juridical package of responsibility and eventually legally determined guilt, and that can be attributed to any legal subject, attached like an external legal appendage to the legal subject.

The Norwegian case of 22 July 2011 demonstrates that the life-giving virtues of societal security are everything but material, and suggests that security takes a far more fundamental form than 'object-security' and should be construed as more than the sum of its material functions. This insight, which will be fleshed out in what follows, can offer a real supplement to current mainstream approaches to societal security. A truly societal approach can generate a security vocabulary that fills the gaps left by the neopositivist assumption that politics is nothing more than the sum of all political utterances, that functionalism is the aggregate of all functions, that insecurity can be adequately captured as the aggregation of all threats, or that security could ever be provided to a society by preventing the destruction of the collection of all material things to which society is attached. If, on the assumption that insecurity is identical to the sum of all threats, we were indeed able to imagine and then set in place measures necessary to eliminate these threats, if societal security were understood as a terminal process, with a finite, totalisable, objective end-state of security zero, then this end-state would be neither desirable nor virtuous. It would not even be society.

\section{The societal ethos of insecurity}

This is not the course that history took. If we return to the immediate aftermath of the attacks, the discourse moves in the opposite direction. In the words and actions of the Norwegian Prime Minister, the bare material facts of the terrorism, what will ten years later become relics of a nation-wide bureaucratisation process, are 'spiritualised'. They are removed from their facticity, from their immediate objectivity from the moment they become established as facts. Out of the brutal reality of the events emerges an uncanny tone of humanity. From the Prime Minister's press conference the evening after the attack: 
This is an evening that demands much of all of us. The days that are coming will demand even more. We are prepared to meet this. Norway stands united in times of crisis. We mourn our dead. We suffer with the injured and we feel with their next of kin. This is about an attack on innocent civilians, on youngsters at a summer camp, on all of us.

(NRK, 2011)

The Prime Minister appeals to a substance that both precedes and transcends the horrible facts of the attack. He evokes the responsibility that the facts demand of Norwegians, and will continue to demand of them, beyond their facticity. What do facts demand? Nothing, of course. Unless, they are transformed or lifted to a plane of accountability, normativity, compassion, affect, and action. All these qualities are in some sense evoked by the Prime Minister. As the events and reactions unfold over the next days, Norwegians and the Norwegian political class showed themselves to be up to the challenge, as the Prime Minister rightly predicts. They reacted to it in terms of their moral, cultural, or spiritual experience, precisely on the terrain where it by nature does the most damage. For while the individual lives lost are tragically irreplaceable, the explicit and real target of terrorism is to weaken, damage, or destroy the moral character of society: its values, its traditions, its historical substance, its forms of culture practice, etc.

Against all scientific reason the facts and values seemed at that moment to be inseparable. Thus, the Prime Minister, in his speech, swerves back to the empirical - 'This is about an attack on innocent civilians, on youngsters at a summer camp' - before again collectivising, consolidating, spiritualising the violence as an attack 'on all of us'. The collective position and ethos continues as the Prime Minister delivers a 'message' to those who have attacked us':

It's a message from all of Norway. You will not destroy us. You will not destroy our democracy, our engagement for a better world. We are a little nation, but we are a proud nation. No one can bomb us into silence. No one will shoot us into silence. No one will ever scare us from being Norway.

(NRK, 2011)

The role of a political leader, representative of a sovereign state, is to send and receive political messages from that state. He or she who possesses the political legitimacy to do so represents the democratically determined general will of the people. Yet the nature and content of the general will of a democratically determined people has long remained a mystery of political philosophy. The rights and obligations granted by the societal contract have accompanied the long pedigree of the nation-state, even if for inexplicable reasons. In this sense, what it means to 'speak for Norway', either war or peace, joy or sorrow, is unclear, though there is little doubt that Norway is 
spoken for, both through and around the person of the Prime Minister. The official bureaucracy, the enlightened public sphere, the political masses all participate, both in form and content, in the expression of 'the Norwegian'. Its institutions and authorities, by carrying on business as usual, by enacting the Norwegian through the customs, traditions, and values they embody.

In the closing sequence of what we can imagine was a speech hastily prepared under trying circumstances, the Prime Minister again plays on the twin chords of Norwegian collective experience - the individual and the collective. 'This evening and tonight', he continues,

we will take care of each other, give each other comfort, talk with each other, stand together. $[, \ldots]$ The most important thing this evening is to save human life, to show care, for all those who have been struck, and their next of kin.

(NRK, 2011)

Surely only in Norway, where the imagined community is small - though in fact over 5 million people - would expressing such a sentiment be possible. It was. Its plausibility stemmed from the presence in national, regional, and local culture of traces of a folk culture, patterns of speech and behaviour, national customs whose pretence is to create comfort for those who understand the codes. It can be witnessed in the Norwegian popular culture, national manifestations, sports events, and social life, even while being gradually displaced by globalising or Europeanising forms of professionalism, administrative and bureaucratic culture, New Public Management, all based on one form or another of the ideology of efficiency as homogenisation, accountability as replicability, and interoperability. This popular culture has also resisted, not without some effort, the marginal trend toward populism, which, compared to Trump's America or the various European new nationalisms, is difficult to take seriously. Norwegians can still, at least according to a certain imaginary, take care of each other, give each other comfort, talk with each other, and stand together. And yet, for the Prime Minister, in the late hours of 22 July 2011, this imagined local imagery is linked to the equally, and necessarily, imagined collective agency of the Norwegian:

Tomorrow we will show that world that Norwegian democracy becomes stronger when it counts. We will find those who are guilty and hold them responsible.

$[\ldots]$

We must never stop standing up for our values. We must show that our open society passes this test too. That the response to violence is even more democracy, even more humanity, but never naivety. We owe that to the victims and their next of kin.

(NRK, 2011) 
The collective Norwegian implicitly knows and understands, according the Prime Minister, what is under threat when the Norwegian is under threat. It is something that transcends the hideous death and injury of individual Norwegians, transcends the horrific material destruction in downtown Oslo. Norway as a society was targeted by the attacks, but the Prime Minister contributes to a discourse, as would many others in the days and weeks that were to come, that seeks to protect society, understood not as a collection of individuals, but as a far richer, deeper, older collection of spiritual values and democratic customs.

The comments by the Prime Minister are in this sense really quite remarkable, unique, perhaps even unheard of in the cultural politics of the post-9/11 era. They can serve as the baseline for an analysis of the gradual bureaucratisation of response to terrorism that was to follow, apparently the only visible path for the political apparatus whose task is to administratively embody the heart and soul of Norwegian society. The Prime Minister, together with others, expresses an idea of societal security that starts a journey, moments after the attacks in Oslo and Utøya, from the preservation of the Norwegian as a spiritual matter to the preservation of the Norwegian as a bureaucratic matter.

\section{Society as a protector and protected}

There is of course a gaping double-meaning at the heart of the concept of societal security. On the one hand, the term refers most commonly to the absence of threat to a thing called 'society'. On the other hand, it refers to a certain kind of security of the kind that is provided by society. Both of these meanings can be readily identified in the contributions to this volume.

The most challenging component in the societal security is undoubtedly society itself. It seems to be so self-evident that few seek to interrogate it. 'Society', one imagines, is what is, was, and will remain, apparently selfevident. There is a kind of chronic indifference to what society is, most notably when society is in political or existential terms. Society is like a blind spot for anyone interested in formulating claims about the security of society. And yet, society inevitably plays a remarkable role during security events, before disaster occur, during, and in the wake of them. On the one hand, there is an understanding of society that positions itself as central actor in a range of functions, as a perceiving, thinking, active, reactive, autonomous entity capable of participating actively in its own security, among other things. On the other hand, it is often understood as the passive recipient of security measures, as that which is under threat, that which is to be protected and preserved. Society thus has a responsibility linked to the ancient social contract, to provide security for its citizens.

What does it mean to say that a society holds responsibility for the security of society? The idea that a given society holds a certain responsibility, a responsibility that other societies do not have, must in some sense stem 
from the principle that it possesses special qualities, special capabilities, and thereby special responsibility to prevent security threats. That society should have 'failed' must mean that the implicit values in society, its properties, its identity, etc., have failed, not the political components that make up what one designates as 'society', its form and substance. It seems clear that the bureaucratic apparatus, with its detailed guidelines, mandates, and instructions, can be held responsible for the correspondence between task and performance. But can society itself? Can a society be held responsible for something other than itself? When and under what circumstances? Which society are we talking about? Whose society, society for whom? Rhetorically speaking, in rock-solid social democracies like the Nordics, 'society' remains the fundamental anchoring point for a tacit understanding of a certain kind of security, security as an aspiration, a norm or societal ambition, even a promise. In this sense societal security is a project, an uncompleted undertaking, an enterprise in the making, one which the collective resources of the nation must participate in. It is against the social democratic backdrop of society as a guarantor of security that society may fail, may let down its obligation to itself.

Thus, the society of societal security nearly appears as a kind of riddle, a question mark, a misunderstood notion, or even an unknown. A variety of understandings of 'society' emerge and disappear. It has many functions, some overlapping, some contradictory, and many ways of being, reprimanding some, praising others. Society appears, on the one hand, as a something under threat, something to be protected. Society is at times taken as the collective expression or symbol for an inherent vulnerability of all citizens. Elsewhere it is an expression of the vulnerability of the state as a sovereign entity. Of course from the national standpoint there is nothing about a given society that is not worth preserving. Like most well-integrated nation-states, society in Norway is itself wrapped up in this logic in a very complex way, through the interlacing of people, organisations, and institutions, on the one hand, and by the long reach of history, tradition, heritage, etc., on the other hand. Society is the primary actor in the project of its own security. Society is in many ways a proxy, a stand-in, for its own security: it acts and is acted upon. By both acting and functioning as a society, it generates security, while at the same time accumulating the value which puts it raises the spectre of the threat of its demise. Society is a security perpetuum mobile.

\section{Homegrown insecurity}

The extraordinary twist in the story of the $22 / 7$ attacks in Norway was that it pulverised the global terror-morality play of the U.S.-orchestrated war against terror. With the devise of Bush Jr.'s "You are either with us or you are with the terrorists!" echoing in their heads, many Norwegians spent the tense afternoon hours of 22/7 imagining the "other" at whose hand they were under attack, and in some cases accosting immigrants on the open 
street for their ingratitude. When it was revealed on the evening news that the terrorist was a blond-haired, middle-class Christian Norwegian, they were forced to realise that it was entirely possible to be 'with us' and 'with the terrorists', that the terrorist other was actually the same, that the Bushian prophylactic project of purifying the world of terrorism was not viable, and that anyone, any Norwegian, any Scandinavian, and human being, could ultimately be a terrorist.

In this sense, all the elements of the new age of uncertainty are present: The dangers we confront today, in particular the threat of terrorist violence, are not exogenous or foreign to the societies they threaten. They are not alien corpuscles to a body-politic that is already safe and secure, spiritually sound and morally righteous on its own right. By the same token, the threat cannot be prevented in becoming a reality by holding it at bay, blocking its contact with the sanctity of the society it threatens. As disconcerting as it may seem, the threat to society is, in the case of Breivik and many others, a creation of that society, a symptom of its own maladies, spill-over from its excesses, penury from its insufficiencies. From a societal point of view, that is, setting aside the relatively extraordinary personal psychological situation that surrounded Breivik during his upbringing and youth (Berntzen and Sandberg, 2014; Leonard et al., 2014; Melle, 2013), Breivik is a product of Norwegian society, its culture, welfare, values, religion, and customs. He benefited in his misdeeds from the social conventions, political liberties, and legal permissiveness enjoyed by any modern liberal society, but most markedly the Norwegian.

This inversion of the threat logic in the experience of terrorism dovetails with the kind of post-Cold War security narrative studied throughout this volume. The evolution in the discourse of security after the Cold War revealed a shift away from the bipolar logic of security - away from an individualised, identifiable source of threat subject to monological, predictable, accountable, predetermined, rational, and finite counter-measures - to a reflexive notion of security characterised by the inward threat of multifarious dangers. A traditional geopolitical threat horizon was replaced by a security imaginary according to which threats are both invisible and immediate. Security went from being an outward focus on a distinct known enemy to an inward focus on a ubiquitous enemy.

The politics of security thus shifts from being about the other to being about us and, most significantly, about the other in us. Danger is sleeping in our imaginations, in our minds, and in our memories. The empirical threats that preoccupy us, like climate change, pandemics, cyberattacks, do not arrive from far out there beyond the wall or beyond the enforced border but rather here in our presence, integrated within society (Burgess, 2015).

The insight at the core of the concept of societal security is that indeed all threats today are homegrown. Not because their perpetrators hold the same passport as their victims. Rather, it is by virtue of the fact that the force of their danger is parasitic on the values of a society. The danger, the fears, the 
risk, and the uncertainty that fuel the insecurities of our time, be they terrorism, pandemic disease, climate change, etc., find their destructive meaning and power not in their objects, but in the societal value configurations that make them attractive. Societal security is for this reason a powerful objective because all threats are societal. Even the most material, 'non-social', objects - in the way that a bridge or an oil-refinery would be a legitimate target for a symmetric military conflict - are ultimately societal, and thus, their insecurity is governed by a societal rationality (Burgess, 2007). As a consequence, all terrorism is homegrown. All insecurity is homegrown because only the 'home' can generate security.

\section{From the collective ethos of the Rose Demonstration}

Perhaps the most remarkable manifestation of the humanist-culturaldemocratic baseline ethos that I have tried to signal in certain parts of the official discourse, primarily in the discourse surrounding the Prime Minister, came from the public demonstration that took place in the evening of 25 July, the so-called 'Rose Demonstration'. The demonstration quickly came to be known by that name because participants were encouraged to come carrying a rose, a logistic feat which, had it been centrally organised, would have doubtless been impossible, but which on a person-by-person basis produced an astonishing and moving manifestation. Estimates varied between 150,000 and 200,000 people, about one third of the population of Oslo (Fuglehaug, 2011; Solberg et al., 2011), and an equally extraordinary embodiment of the solidarity and unity was thematised through the songs, poems, and speeches that were represented. The crowd was addressed by the Prime Minister and others before Crown Prince Haakon gave a speech that seemed to capture the mood of a nation.

The speech was the antidote to any kind of escalation or militarisation as a result of the attacks, to vengeance or retribution. It focused on unity and solidarity in a way that echoed the Prime Minister in the preceding days, and, above all, it emphasised the responsibility all Norwegians hold, to be clear about the fundamental societal values that are under threat and the response we should make to this threat, namely, through a re-assertion of the values of openness and democracy. The speech was reproduced over the entire front page of Aftenposten, Norway's largest print newspaper:

This evening the streets are filled with love; we have chosen to answer cruelty with closeness; we have chosen to meet hate with unity; we have chosen to show what we stand for

$[\ldots]$

Norway is a country in grief; we think of all those who have suffered loss, who are missing; of all those who made a historical effort to save life and to re-establish our security; and of our leaders who have been 
forced to face difficult trials in the last days; those who were on Utøya and in the Government Quarter were targets for terror, but it afflicted us all.

$[\ldots]$

After July 22 we can never again permit ourselves to think that our opinions and our attitudes are without meaning; we have to be there every day, armed in the fight for the free and open society we love so much

[...]

The Norway we want, no one will take from us; we are facing a choice. We cannot undo what has been done; but we can choose what it will do with us as a society and as individuals; we can chose that no one must stand alone; we can choose to stand together

[...]

It is up to each and every one of us now; it's up to you and it's up to me; together we have a job to do; it's a job that is done around the dinner table, in the cantina, in the clubs, among volunteers, by men and women, in the counties and in the cities.

(Haakon 2011)

The speech contains an appeal to unity, an appeal to meet hate with love, to feel and speak freely. It is a call to think about society and fellowship, about who Norwegians are and what they are, what it means, culturally, spiritually, to be a Norwegian; what 'the Norwegian' oblige Norwegians to do; and, not least, what kind of actions and attitudes it is incompatible with. It might have come across as a series of clichés and banalities coming from a tall, impeccably dressed man. But the presence of an intensely present crowd, spontaneously singing the Norwegian national anthem ('Yes, we love this land') and other well-known folk songs, somehow gave body to the message, performed it in a way that was unique, particularly, in an era of tough talk, militarisation and authoritarianism, and against terror.

Following the speech of the Crown Prince, Prime Minister Jens Stoltenberg again took the stage with his societal discourse, perhaps the last time in the course of the national grief process, when that discourse would stand unadulterated or even stand at all.

Thousands and thousands of Norwegians in Oslo and over the whole country are doing the same thing this evening. They are conquering the streets, the marketplaces, the public spaces, with the same stubborn message: "we are heartbroken but we do not give up". With torches and roses, we give the world notice: we do not let fear break us, and we don't let the fear of fear silence us. The sea of people before me and the warmth I feel from the country make me certain in my conviction: Evil can kill a person, but never conquer an entire people. 
$[\ldots]$

There will be a Norway before and a Norway after 22 July 2011. But we will decide which Norway. More openness, more democracy, resoluteness and strength - that is us, that is Norway. We will take back our security. Out of all of the pain we glimpse, paradoxically enough, roots of something valuable. What we see this evening can be the greatest and most important march we have set out upon since World War 2: A march for democracy, a march for unity, a march for tolerance.

(Stoltenberg, 2011)

Not unexpectedly, simultaneous with the discourse of unity, of 'the Norwegian', and of societal values, a discourse of accountability in a more or less narrow sense blossomed. During the three weeks between the attacks and the formal creation of the 22 July Commission, meant to review the events in their broad context, a number of critiques of the actions of the police, emergency services, ambulance services, the Ministries of Defence and Justice, the Office of Public Works, local and national authorities, lawmakers, budget-makers, and, not least, the government emerged (Dragnes, 2011; Fuglehaug et al., 2011).

But by far the most prominent and emotional critique raised against public authorities in the wake of the attacks concerned the time required for the police to arrive at Utøya. This would lead to a more or less instrumentalised claim that since the terrorist could have stopped earlier, more lives could have been saved. Since subsequent forensic analysis and reconstructions were able to pin-point the precise time of death of each victim, highly speculative suppositions emerged, in part supported by the 22 July Commission report, that the closer a victim's death was to the conclusion of the shooting rampage, the more dependent it was on the efficiency of the commandos in obtaining a cease-fire. This instrumental reasoning of life-and-death would tend to support and advance both a variable scale of responsibility of the public services for the deaths of individuals - the closer to the cease-fire, the more responsible - and a variation in the 'saveability' of life itself - those who died later being forever regarded as more 'saveable' than those who died early.

\section{Toward societal security}

As this book attests, approaches to understanding societal insecurity vary almost as widely as approaches to conceptualising terrorism. Psychological approaches seek to understand violent extremism as part of an internal determinism or link to group influence. Societal approaches try to draw lessons from group interactions and institutions. Cultural analyses focus on cultural interactions, and above all, conflicts. Political approaches underscore the channels of political expression and the availability of political institutions for enacting changes. Legal approaches focus on the function of 
local, national, and international regulatory measures. But like most scholarly approaches, these attempts to come to grips with violent extremism reflect as much their own starting points, premises, and values, as they do the object they seek to study.

What is however a constant is that societal insecurity, in essentially all of its forms, grows in a paradoxical way out of modern liberal society. It is paradoxical because, in more or less all cases, it is, on the one hand, a reaction to the values of liberalism and, on the other hand, made possible by the channels of free self-expression that are in turn made available by liberal society. The link between liberalism and extremism becomes clear when we consider the paradox at the heart of liberalism. All societies, from liberal to authoritarian, from democracies to informal communities to business partnerships, have one trait in common: they rest upon a bond. This bond is not a given. It is not a necessity, cannot be taken for granted, no matter what the setting is. More importantly, this bond cannot be forced. It is in-compatible with force. Thus, force, or even violence, as an expression of a social pact is simply incoherent.

\section{References}

Arter, D. 1999. Scandinavian Politics Today, Manchester, Manchester University Press.

Aylott, N. 2014. Models of democracy in Nordic and Baltic Europe: Political Institutions and Discourse, Farnham; Burlington, VT, Ashgate Publishing Company.

Berntzen, L. E. \& Sandberg, S. 2014. The Collective Nature of Lone Wolf Terrorism: Anders Behring Breivik and the Anti-Islamic Social Movement. Terrorism and Political Violence, 26, 759-779.

Brandal, N., Bratberg, I. \& Thorsen, D. E. 2013. The Nordic Model of Social Democracy, Basingstoke, Palgrave Macmillan.

Burgess, J. P. 2007. Social Values and Material Threat. The European Programme for Critical Infrastructures Protection. International Journal of Critical Infrastructures, 3, 471-486.

Burgess, J. P. 2015. An Ethics of Security. In: Schlag, G., Junk, J. \& Daase, C. (eds.) Transformations of Security Studies: Dialogues, Diversity and Discipline. London: Routledge.

Childs, M. W. 1936. Sweden: The Middle Way, London, Faber \& Faber.

Dølvik, J. E. 2007. The Nordic Regimes of Labour Market Governance: From Crisis to Success-Story. Fafopaper. Oslo: Forsvaretsforskningsinstitutt.

Dragnes, K. 2011. Oppsplittet beredskap. Aftenposten, 11 August 2011.

Fuglehaug, W. 2011. Kvelden Norge viste samhold og styrke. Aftenposten, 26 July 2011.

Fuglehaug, W., Johansen, P. A., Guhnfeldt, C. \& Øverli, L. A. E. 2011. Terrorøvelser avslørte beredskapsmangler. Aftenposten, 27 July 2019.

Greve, C., Lægreid, P. \& Rykkja, L. H. 2016. The Nordic Model Revisited: Active Reformers and High Performing Public Administrations. In: Greve, C., Lægreid, P. \& Rykkja, L. H. (eds.) Nordic Administrative Reforms. Munich: Springer.

Haakon, H. K. H. K. 2011. Kronprinsens appell på Rådhusplassen. Oslo: Det norske kongehus. 
Helliwell, J. F., Layard, R. \& Sachs, J. D. 2019. World Happiness Report 2019. New York: Sustainable Development Solutions Network.

Hilson, M. 2008. The Nordic Model: Scandinavia since 1945, London, Reaktion.

Kvist, J. \& Fritzell, J. 2011. Changing Social Equality: The Nordic Welfare Model in the 21st Century, London, Policy Press.

Kvist, J. \& Greve, B. 2011. Has the Nordic Welfare Model Been Transformed? Social Policy \& Administration, 45, 146-160.

Leonard, C. H., Annas, G. D., Knoll IV, J. L. \& Tørrissen, T. 2014. The Case of Anders Behring Breivik-Language of a Lone Terrorist. Behavioral Sciences \& the Law, 32, 408-422.

Melle, I. 2013. The Breivik Case and What Psychiatrists Can Learn from It. World Psychiatry, 12, 16-21.

NRK. 2011. Dagsrevyen [Online]. Norwegian Broadcasting Company. Available: https://tv.nrk.no/serie/dagsrevyen/201107/NNFA19072211/avspiller [Accessed June 7, 2020.].

NTB. 2016. Listhaug: Parallellsamfunn et resultat av snillisme. Aftenposten, 9 May. Solberg et al., H. 2011. Da folket tok Norge tilbake. $V G$.

Stoltenberg, J. 2011. Statsministerens tale til rosetoget etter terroren 22.07.11 [Online]. Norges rikskringkastning. Available: www.nrk.no/video/PS*43214 [Accessed].

Witoszek, N. 2011. The Origins of the "Regime of Goodness": Remapping the Cultural History of Norway, Oslo, Norwegian University Press. 